Published in final edited form as:

Eur J Neurosci. 2005 December ; 22(12): 3137-3146.

\title{
Direct pyrogenic input from prostaglandin EP3 receptor- expressing preoptic neurons to the dorsomedial hypothalamus
}

\author{
Yoshiko Nakamura ${ }^{1,2,3}$, Kazuhiro Nakamura ${ }^{1,2}$, Kiyoshi Matsumura $^{3,}{ }^{*}$, Shigeo \\ Kobayashi $^{3}$, Takeshi Kaneko ${ }^{2,4}$, and Shaun F. Morrison ${ }^{1}$ \\ 1 Neurological Sciences Institute, Oregon Health \& Science University, 505 NW 185th Avenue, Beaverton, \\ Oregon 97006, U.S.A. \\ 2Department of Morphological Brain Science, Graduate School of Medicine, Kyoto University, Sakyo-ku, \\ Kyoto 606-8501, Japan \\ 3Department of Intelligence Science and Technology, Graduate School of Informatics, Kyoto University, \\ Sakyo-ku, Kyoto 606-8501, Japan \\ 4Core Research for Evolution Science and Technology, Japan Science and Technology, Kyoto University, \\ Sakyo-ku, Kyoto 606-8501, Japan
}

\section{Abstract}

Fever is induced by the neuronal mechanism in the brain. Prostaglandin $(\mathrm{PG}) \mathrm{E}_{2}$ acts as a pyrogenic mediator in the preoptic area (POA) probably through the EP3 subtype of PGE receptor expressed on GABAergic neurons, and this $\mathrm{PGE}_{2}$ action triggers neuronal pathways for sympathetic thermogenesis in peripheral effector organs including brown adipose tissue (BAT). To explore pyrogenic efferent pathways from the POA, we here determined projection targets of EP3 receptorexpressing POA neurons with a special focus on rat hypothalamic regions including the dorsomedial hypothalamic nucleus (DMH), which is known as a center for autonomic responses to stress. Among injections of cholera toxin b-subunit $(\mathrm{CTb})$, a retrograde tracer, into hypothalamic regions at the rostrocaudal level of the $\mathrm{DMH}$, injections into the $\mathrm{DMH}$, lateral hypothalamic area $(\mathrm{LH})$, and dorsal hypothalamic area (DH) resulted in EP3 receptor immunolabeling in substantial populations of CTblabeled neurons in the POA. Bilateral microinjections of muscimol, a $\mathrm{GABA}_{\mathrm{A}}$ receptor agonist, into the DMH and a ventral region of the DH, but not those into the $\mathrm{LH}$, inhibited thermogenic (BAT sympathetic nerve activity, BAT temperature, core body temperature, and expired $\mathrm{CO}_{2}$ ) and cardiovascular (arterial pressure and heart rate) responses to an intra-POA $\mathrm{PGE}_{2}$ microinjection. Further immunohistochemical observations revealed close association of POA-derived GABAergic axon swellings with DMH neurons projecting to the medullary raphe regions where sympathetic premotor neurons for febrile and thermoregulatory responses are localized. These results suggest that a direct projection of EP3 receptor-expressing POA neurons to the $\mathrm{DMH} / \mathrm{DH}$ region mediates febrile responses via a GABAergic mechanism.

\section{Keywords}

cardiovascular regulation; hyperthermia; sympathetic nervous system; stress response; thermoregulation

\footnotetext{
Correspondence: Dr Kazuhiro Nakamura, Neurological Sciences Institute, as above. E-mail: nakamura@ohsu.edu.

* Present address: Department of Information Science and Technology, Osaka Institute of Technology, 1-79-1 Kitayama, Hirakata-City, Osaka 573-0196, Japan
} 


\section{Introduction}

Fever is one of the most basic symptoms that appear in various pathological situations, and therefore, the mechanism that produces fever has been an important medical topic since ancient days (Atkins \& Bodel, 1972; Kluger, 1991). Fever production is controlled by neuronal systems in the brain, and major components of febrile responses are thought to be triggered in the preoptic area (POA) by an action of prostaglandin $(\mathrm{PG}) \mathrm{E}_{2}$, which is synthesized in response to immune signals (Elmquist et al., 1997; Matsumura et al., 1998; Yamagata et al., 2001). Among the subtypes of PGE receptors expressed in the POA (Oka et al., 2000), the EP3 receptor subtype is localized in the somatodendritic portion of POA neurons (Nakamura et al., 1999, 2000), and analyses of mice lacking each of the known PGE receptor subtypes showed that only EP3 receptor-deficient mice completely failed to show a febrile response to $\mathrm{PGE}_{2}$, interleukin-1 $\beta$, or endotoxin (Ushikubi et al., 1998), although EP1 receptor-deficient ones showed a partial attenuation of endotoxin-induced fever (Oka et al., 2003). These lines of evidence suggest that the EP3 receptor on POA neurons is the principal target site of $\mathrm{PGE}_{2}$ for its pyrogenic action and that the receptor activation by $\mathrm{PGE}_{2}$ triggers the neuronal processes for fever induction.

Fever generally involves multiple physiological effector functions including thermogenic, cardiovascular, and neuroendocrine responses. Fever-associated thermogenesis is finally developed by peripheral sympathetic effectors including brown adipose tissue (BAT), which is the major thermogenic organ in rodents (Rothwell, 1992). Fever-inducing sympathetic efferent pathways from the POA have been investigated by many studies (For reviews, see Morrison, 2004; Nakamura, 2004; Nakamura et al., 2005). It has been shown that a region in medullary raphe nuclei mediates $\mathrm{PGE}_{2}$-triggered fever signals leading to sympathetic thermogenesis (Nakamura et al., 2002; Madden \& Morrison, 2003; Morrison, 2003) likely through the direct pathway from raphe sympathetic premotor neurons to sympathetic preganglionic neurons (Nakamura et al., 2004). Although the medullary raphe region has been shown to receive a direct projection from EP3 receptor-expressing POA neurons (Nakamura et al., 2002), it is still possible that other brain regions intercalatedly mediate fever signals from the POA to the medullary raphe region.

One of the most likely candidates for such brain regions is the dorsomedial hypothalamic nucleus (DMH), which is an important site for autonomic responses to certain stress stimuli (For review, see DiMicco et al., 2002) and receives many projections from various brain regions including the POA (Thompson \& Swanson, 1998). However, these projections have been poorly understood in conjunction with the stress-related autonomic functions mediated by the DMH. If EP3 receptor-expressing POA neurons, most of which are positive for a GABAergic neuronal marker (Nakamura et al., 2002), directly project to hypothalamic autonomic regions including the $\mathrm{DMH}$, such projections could mediate febrile responses to immune stress via a mechanism involving the GABAergic neurotransmission. In the present study, we anatomically explored direct projections of EP3 receptor-expressing POA neurons to several hypothalamic regions including the $\mathrm{DMH}$, and physiologically examined the functional involvement of these projections in the fever-inducing neuronal mechanism.

\section{Materials and Methods}

\section{Animals}

Male Wistar (200-300 g body weight) and Sprague-Dawley (250-450 g) rats were used for anatomical and physiological studies, respectively. We confirmed that both strains show febrile responses with similar profiles in response to $\mathrm{PGE}_{2}$ microinjection into the POA. They were housed two or three to a cage with ad libitum access to food and water in a room air-conditioned at $24 \pm 2^{\circ} \mathrm{C}$ with a standard $12 \mathrm{~h} \mathrm{light/dark} \mathrm{cycle.} \mathrm{All} \mathrm{procedures} \mathrm{conform} \mathrm{to} \mathrm{the} \mathrm{rules} \mathrm{of} \mathrm{animal}$ 
care of the Institute of Laboratory Animals, Faculty of Medicine, Kyoto University and were approved by the Animal Care and Use Committee of the Oregon Health \& Science University.

\section{Tracer injection}

Rats were deeply anesthetized with chloral hydrate $(280 \mathrm{mg} / \mathrm{kg}$, i.p. $)$ and placed in a stereotaxic apparatus; the incisor bar level was adjusted so that the bregma and lambda were at the same dorsal level. For anterograde tracing studies, we used a replication-deficient recombinant Sindbis virus containing a gene encoding enhanced green fluorescent protein (EGFP) tagged with the $\mathrm{N}$-terminal palmitoylation signal peptide of growth associated protein-43 (Moriyoshi et al., 1996) that was driven by a subgenomic promoter of Sindbis virus for expression in mammalian cells (Furuta et al., 2001). The virus solution (0.1-0.5 $\mu 1,2 \times 10^{10}$ infectious unit/ $\mathrm{ml}$ ) was pressure-injected into the POA through a glass micropipette (tip inner diameter 10$20 \mu \mathrm{m}$ ) with the aid of a Picospritzer II (General Valve, Fairfield, NJ, U.S.A.). The coordinates for the POA were $0-0.1 \mathrm{~mm}$ posterior to the bregma, $0.5-0.7 \mathrm{~mm}$ lateral to the midline, and 7.5-8.5 mm ventral to the brain surface. For retrograde tracing studies, $1.0 \mu \mathrm{g} / \mu \mathrm{l}$ Alexa594conjugated cholera toxin b-subunit (CTb; 0.1-0.2 $\mu$; Molecular Probes, Eugene, OR, U.S.A.) or 4\% Fluoro-Gold (0.1-1.0 $\mu \mathrm{l}$; Fluorochrome, Denver, CO, U.S.A.) was pressure-injected into hypothalamic regions $(2.8-3.3 \mathrm{~mm}$ posterior to the bregma, $0.3-2.2 \mathrm{~mm}$ lateral to the midline, and 7.5-9.5 mm ventral to the brain surface) or into the rostral raphe pallidus region ( $2.3 \mathrm{~mm}$ posterior to the interaural line, on the midline, and $9.3-9.5 \mathrm{~mm}$ ventral to the brain surface).

Eighteen hours after the virus injection or 3-4 days after the CTb or Fluoro-Gold injection, each animal was re-anesthetized and transcardially perfused with $100-150 \mathrm{ml}$ of a $0.9 \%$ sodium chloride solution and then with $200-300 \mathrm{ml}$ of $4 \%$ formaldehyde in $0.1 \mathrm{M}$ phosphate buffer (pH 7.4). The brain was removed, postfixed in the fixative at $4^{\circ} \mathrm{C}$ for $2-3 \mathrm{~h}$, and then cryoprotected with a $30 \%$ sucrose solution overnight. The tissue was cut into $20-\mu \mathrm{m}$-thick frontal sections on a freezing microtome. For double injections of CTb and Sindbis virus, CTb was first injected 3 days before virus injection, and $18 \mathrm{~h}$ after the virus injection, the animals were perfused.

\section{Immunohistochemistry}

Immunohistochemical procedures were based on our previous studies (Nakamura et al., 2000, 2001). For immunoperoxidase staining, the brain sections were incubated overnight with an anti-EGFP rabbit antibody $(0.1 \mu \mathrm{g} / \mathrm{ml}$; Tamamaki et al., 2000) or an anti-Fluorescent Gold rabbit antibody (1:5,000; Chemicon, Temecula, CA, U.S.A.) and then for $1 \mathrm{~h}$ with $10 \mu \mathrm{g} / \mathrm{ml}$ biotinylated donkey antibody to rabbit IgG (Chemicon). The sections were further incubated for $1 \mathrm{~h}$ with avidin-biotinylated peroxidase complex (ABC-Elite; 1:50; Vector, Burlingame, CA, U.S.A.). Bound peroxidase was visualized by incubating the sections with $0.02 \% 3,3^{\prime}-$ diaminobenzidine tetrahydrochloride (Dojindo, Kumamoto, Japan) and $0.001 \%$ hydrogen peroxide in $50 \mathrm{mM}$ Tris- $\mathrm{HCl}(\mathrm{pH}$ 7.6).

For double immunofluorescence staining, endogenous peroxidase and avidin and biotin in the sections were blocked with $0.3 \%$ hydrogen peroxide and an avidin-biotin blocking kit (Vector), respectively. The sections were incubated overnight with a mixture of an anti-EP3 receptor rabbit antibody $(0.5 \mu \mathrm{g} / \mathrm{ml}$; Nakamura et al., 1999) and an anti-CTb goat serum (1:20,000; List Biological Laboratories, Campbell, CA, U.S.A.). The sections were incubated for $1 \mathrm{~h}$ with 10 $\mu \mathrm{g} / \mathrm{ml}$ biotinylated donkey antibody to rabbit IgG. In the presence of $10 \%$ normal rabbit serum, the sections were further incubated for $1 \mathrm{~h}$ with $10 \mu \mathrm{g} / \mathrm{ml}$ Alexa594-conjugated donkey antibody to goat IgG (Molecular Probes) and then for $1 \mathrm{~h}$ with ABC-Elite (1:50). The peroxidase reaction was finally performed by incubating the sections with fluoresceinconjugated tyramide (Tyramide Signal Amplification fluorescence systems; 1:50; 
PerkinElmer, Boston, MA, U.S.A.) for 3 min. The sections were thoroughly washed and mounted onto gelatin-coated glass slides. For double-fluorescence microscopy, an epifluorescence microscope (Axioplan 2; Zeiss, Oberkochen, Germany) was used with an appropriate filter set for fluorescein (excitation, $450-490 \mathrm{~nm}$; emission, $515-565 \mathrm{~nm}$ ), or Alexa594 (excitation, $530-585 \mathrm{~nm}$; emission, $\geq 615 \mathrm{~nm}$ ).

For triple immunofluorescence staining, sections were incubated overnight with a mixture of an anti-CTb goat serum $(1: 20,000)$, an anti-EGFP guinea pig serum $(1: 1,000)$ and an antivesicular GABA transporter (VGAT) rabbit antibody (1:1,000; Chemicon). The sections were incubated for $1 \mathrm{~h}$ with $10 \mu \mathrm{g} / \mathrm{ml}$ biotinylated donkey antibody to guinea pig $\operatorname{IgG}$ (Chemicon). In the presence of $10 \%$ normal guinea pig serum, the sections were incubated for $1 \mathrm{~h}$ with 10 $\mu \mathrm{g} / \mathrm{ml}$ Alexa594-conjugated donkey antibody to goat IgG. After blocking for $30 \mathrm{~min}$ with $10 \%$ normal goat serum, the sections were further incubated with $10 \mu \mathrm{g} / \mathrm{ml}$ Alexa633-conjugated goat antibody to rabbit IgG and $5 \mu \mathrm{g} / \mathrm{ml}$ Alexa488-conjugated streptavidin (Molecular Probes). The sections were observed under a confocal laser-scanning microscope (LSM 5 PASCAL; Zeiss).

\section{Anatomy and cell counting}

The cytoarchitecture and nomenclature of Paxinos \& Watson (1998) were adopted in most brain regions and, for the definition of the medial preoptic area (MPO) and median preoptic nucleus (MnPO), we referred to a rat brain atlas by Swanson (1992). Cell counting was made in every six $20-\mu \mathrm{m}$-thick frontal sections throughout the POA. EP3 receptor and CTb immunoreactivities were localized intracellularly in extranuclear structures, and cell nuclei were identified as an intracellular structure negative for these immunoreactivities. Thus, only immunoreactive cell bodies with dark nuclei were counted and plotted on diagrams, but any cellular fragments without cell nuclei were not identified as cell bodies.

\section{Physiological experiment}

Rats were anesthetized intravenously with urethane $(0.8 \mathrm{~g} / \mathrm{kg})$ and $\alpha$-chloralose $(80 \mathrm{mg} / \mathrm{kg})$ after cannulation of a femoral artery, a femoral vein, and the trachea under anesthesia with $3 \%$ isoflurane in $100 \% \mathrm{O}_{2}$. To record arterial pressure (AP) and heart rate (HR), the arterial cannula was attached to a pressure transducer. The animals were positioned in a stereotaxic apparatus with a spinal clamp on the tenth thoracic vertebra, paralysed with D-tubocurarine ( $0.6 \mathrm{mg}$ i.v. initial dose, supplemented with $0.3 \mathrm{mg}$ every $1 \mathrm{~h}$ ), and artificially ventilated with $100 \% \mathrm{O}_{2}(60$ cycles/min, tidal volume: $3.5 \mathrm{ml}$ ). Mixed expired $\mathrm{CO}_{2}$ was measured using a capnometer, and rectal temperature $\left(\mathrm{T}_{\text {rec }}\right)$ was monitored using a copper-constantan thermocouple inserted into the rectum. $\mathrm{T}_{\text {rec }}$ was maintained at $37.0-37.5^{\circ} \mathrm{C}$ with a heat lamp and a heating plate beneath the animal.

Postganglionic BAT sympathetic nerve activity (SNA) was recorded from the central cut end of a nerve bundle isolated from the ventral surface of the right interscapular BAT pad after dividing it along the midline and reflecting it laterally. The nerve bundle was placed on bipolar hook electrodes and soaked in mineral oil. Nerve activity was filtered $(1-300 \mathrm{~Hz})$ and amplified ( $\times 20,000-50,000)$ with a CyberAmp 380 (Axon Instruments, Union City, CA, U.S.A.). BAT temperature $\left(\mathrm{T}_{\mathrm{BAT}}\right)$ was monitored with a copper-constantan thermocouple inserted into the intact left interscapular BAT pad. Physiological variables were recorded onto a personal computer using Spike 2 software (CED, Cambridge, U.K.).

The animals received a unilateral microinjection of $1 \mathrm{mg} / \mathrm{ml} \mathrm{PGE} 2(60 \mathrm{nl}$, dissolved in saline) into the POA through a glass micropipette (20-30 $\mu \mathrm{m}$ tip inner diameter) with the aid of a Picospritzer II. The $\mathrm{pH}$ of the $\mathrm{PGE}_{2}$ solution was adjusted to 7.0 and the aliquots were stored frozen until immediately before use. About 10 min after the $\mathrm{PGE}_{2}$ microinjection, the 
$\mathrm{GABA}_{\mathrm{A}}$ receptor agonist muscimol $(2 \mathrm{mM}, 60 \mathrm{nl}$, dissolved in saline) or saline was bilaterally microinjected into hypothalamic regions including the DMH. To mark the injection sites, 10 $\mathrm{nl}$ of $0.2 \%$ fluorescent microspheres ( $0.1 \mu \mathrm{m}$ diameter; Molecular Probes) in saline was injected at the same stereotaxic coordinates through the same micropipette. After the physiological recordings, the animals were transcardially perfused with a $10 \%$ formaldehyde solution, and the brains were cryoprotected with a $30 \%$ sucrose solution overnight. After the tissue was sectioned at a thickness of $40 \mu \mathrm{m}$ with a freezing microtome, the locations of the microinjections were identified by detecting the fluorescent microspheres under an epifluorescence microscope.

Spike 2 software was used to obtain a continuous measure (4-s bins) of BAT SNA amplitude by calculating the root mean square amplitude of the BAT SNA (square root of the total power in the 0 to $20 \mathrm{~Hz}$ band) from the autospectra of sequential 4-s segments of BAT SNA. Control (baseline) values of all physiological variables were the averages during the 1-min period immediately prior to $\mathrm{PGE}_{2}$ microinjection into the POA. Response values after $\mathrm{PGE}_{2}$ microinjection were the averages during the 1-min period immediately prior to the first muscimol or saline microinjection into hypothalamic regions. Effect values after muscimol or saline microinjections were the averages during the 1-min period following $3 \mathrm{~min}$ (10 min only for $\mathrm{T}_{\mathrm{rec}}$ ) after the second microinjection of muscimol or saline. All physiological data are presented as the means \pm SEM. Statistical analyses were performed using a one-way factorial ANOVA (Instat 2.00 program; Graph Pad, San Diego, CA, U.S.A.) to detect significant differences among groups with saline or muscimol microinjections into the DMH or lateral hypothalamic area $(\mathrm{LH})$. All the DMH-saline $(\mathrm{n}=4)$, LH-saline $(\mathrm{n}=4)$, and LH-muscimol ( $\mathrm{n}$ $=5$ ) microinjections shown in Fig. 3e were used as group data for the statistical analyses, and the DMH-muscimol data for the statistical analyses were selected from the ones shown in Fig. 3e using an anatomical criteria: i.e., the six microinjections closest to the compact part of the DMH. To detect pairwise differences, we used a Bonferroni post hoc multiple comparisons and results were considered significant given a $P$ value of $<0.05$.

\section{Results}

\section{Projection of EP3 receptor-expressing POA neurons}

Although it is known that numerous neuronal projections to the DMH are provided by several subregions of the POA (Simerly \& Swanson, 1988; Thompson \& Swanson, 1998), projections from the MPO, where many EP3 receptor-expressing neurons are localized, have scarcely been explored. At the beginning of the present study, we performed an anterograde tracing study to examine the distribution of MPO-derived axons in hypothalamic regions at the rostrocaudal level of the DMH by using a highly sensitive anterograde tracing technique that was developed by Furuta et al. (2001). This technique uses a replication-defective recombinant Sindbis virus that was designed for the infected cells to express a membrane-targeted form of EGFP (Moriyoshi et al., 1996), enabling us to label the infected neurons in a Golgi stain-like manner. The Sindbis virus was injected unilaterally into the MPO, covering the region where EP3 receptor-expressing neurons are localized (Nakamura et al., 1999, 2000; see Fig. 4c), and infected neurons exhibited EGFP-fluorescence (Fig. 1a). EGFP-immunoreactive axon fibers derived from the infected neurons were widely distributed in hypothalamic regions at the level of the DMH ipsilateral to the site of the virus injection (Fig. 1b). Immunoreactive axons were dense in the $\mathrm{DMH}$, medial tuberal nucleus, dorsal hypothalamic area (DH), and medial part of the LH, and fewer in the arcuate nucleus and lateral part of the LH, but almost none in the ventromedial hypothalamic nucleus and zona incerta. Immunoreactive axon fibers were associated with many EGFP-immunoreactive boutons (Fig. 1c, arrowheads).

To determine whether EP3 receptor-expressing neurons in the POA contribute to the direct projections revealed with the anterograde tracing, we made unilateral injections of $\mathrm{CTb}, \mathrm{a}$ 
retrograde tracer, into hypothalamic regions at the rostrocaudal level of the DMH (Fig. 2a and b) and examined EP3 receptor-immunoreactivity in CTb-labeled neurons in the POA. The CTb injections resulted in retrograde labeling in many neurons throughout the MPO and $\mathrm{MnPO}$ (Fig. 2d), and some of these CTb-labeled neurons were immunoreactive for the EP3 receptor (Fig. 2c, $\mathrm{c}^{\prime}$, and d). To quantitatively evaluate the projection sites of EP3 receptor-expressing POA neurons, we calculated, for each of the injections into hypothalamic regions with $\mathrm{CTb}$, the percentage of $\mathrm{CTb}$-labeled neurons within the POA that were EP3 receptor-immunoreactive (Table 1). As shown in Fig. 2b, CTb injections located mainly in the DMH, LH, and DH labeled higher percentages of EP3 receptor-immunoreactive neurons (dark gray regions) than those into the ventromedial hypothalamic nucleus, medial tuberal nucleus, arcuate nucleus, zona incerta, and subincertal nucleus (light gray regions). The mean percentage values between the former and latter injection groups were significantly different $(P<0.0001$, unpaired Student's $t$ test).

\section{Physiological evaluation of the regions that mediate fever signals from the POA}

The above anatomical observations indicate that EP3 receptor-expressing POA neurons project directly to the $\mathrm{DMH}, \mathrm{LH}$, and $\mathrm{DH}$. To examine the functional relevance of these projections for fever induction from the POA, we tested the effects of muscimol-induced inhibition of neurons in the $\mathrm{DMH}, \mathrm{DH}$ or $\mathrm{LH}$ on febrile responses to microinjection of $\mathrm{PGE}_{2}$ into the $\mathrm{POA}$ by monitoring BAT SNA, $\mathrm{T}_{\mathrm{BAT}}, \mathrm{T}_{\text {rec }}$ (core body temperature), expired $\mathrm{CO}_{2}$, mean $\mathrm{AP}$ (MAP), and HR. Unilateral $\mathrm{PGE}_{2}$ microinjection into the POA (Fig. 3f) reproducibly increased BAT SNA by $1359 \pm 348 \%$ of control $(\mathrm{n}=19)$. The increase in BAT SNA was completely suppressed ( $96 \pm 5 \%$ inhibition of peak $\mathrm{PGE}_{2}$-evoked increase; Table 2) by bilateral microinjections of muscimol into the DMH (Fig. $3 \mathrm{~b}$ and g), and the inhibitory change was significantly different $(P<0.001)$ from the effect of bilateral saline microinjections into the DMH $(-0.3 \pm 4 \%$ inhibition of peak $\mathrm{PGE}_{2}$-evoked increase; Table 2, Fig. 3a). In contrast, muscimol microinjections into the LH had no significant effect on the increase in BAT SNA evoked by an intra-POA PGE 2 microinjection (Fig. $3 \mathrm{c}$ and d, Table 2; muscimol into LH: $-5 \pm 5 \%$ inhibition of peak $\mathrm{PGE}_{2}$-evoked increase; saline into LH: $\left.-2 \pm 2 \% ; P>0.05\right)$. As shown in Fig. 3e, the sites of muscimol microinjections that largely suppressed (> $80 \%$ inhibition) the $\mathrm{PGE}_{2}$-evoked increase in BAT SNA were distributed in the DMH and a ventral part of the DH, whereas muscimol microinjections into the LH or medial tuberal nucleus had no inhibitory effect ( $<10 \%$ inhibition) on the $\mathrm{PGE}_{2}$-evoked BAT sympathoexcitation.

$\mathrm{PGE}_{2}$ microinjection into the POA also increased other physiological variables: $\mathrm{T}_{\mathrm{BAT}}$ by 1.7 $\pm 0.3^{\circ} \mathrm{C}, \mathrm{T}_{\text {rec }}$ by $0.5 \pm 0.1^{\circ} \mathrm{C}$, expired $\mathrm{CO}_{2}$ by $1.0 \pm 0.1 \%$, MAP by $21 \pm 3 \mathrm{mmHg}$, and HR by $106 \pm 12 \mathrm{bpm}(\mathrm{n}=19)$. As shown in Table 2, the increases in $\mathrm{T}_{\mathrm{BAT}}$, expired $\mathrm{CO}_{2}, \mathrm{MAP}$, and HR were also attenuated by $35-81 \%$ by muscimol microinjections into the DMH (Fig. 3b), and all these inhibitory changes were significantly different from those after saline microinjections into the DMH (Fig. 3a). Because changes in $\mathrm{T}_{\text {rec }}$ occurred more slowly than those in other variables (Fig. 3a-d), values of $\mathrm{T}_{\text {rec }}$ were obtained at $10 \mathrm{~min}$ after muscimol or saline microinjections instead of 3 min chosen for the other variables. At this time point, muscimol microinjections into the DMH attenuated $\mathrm{T}_{\text {rec }}$ by $0.2 \pm 0.1^{\circ} \mathrm{C}$ (Table 2, Fig. 3b), but saline injections did not stop the $\mathrm{T}_{\text {rec }}$ rise (increased by $0.3 \pm 0.3^{\circ} \mathrm{C}$; Table 2, Fig. 3a), although the difference was not significant. There were no significant differences between the values of any of the physiological variables following muscimol microinjections into the LH and those following saline microinjections into the LH (Table 2, Fig. 3c and d).

\section{GABAergic input from the POA onto DMH neurons that project to medullary raphe sympathetic premotor regions}

We have previously reported that the majority (86.3\%) of EP3 receptor-immunoreactive POA neurons were positive for a GABAergic neuronal marker (Nakamura et al., 2002). Thus, it is 
likely that some of these POA neurons provide a GABAergic input to the DMH neurons that mediate signals to sympathetic premotor neurons for febrile and thermoregulatory responses, which are located in medullary raphe regions including the rostral raphe pallidus and the raphe magnus nuclei (Morrison, 2004; Nakamura, 2004; Nakamura et al., 2004; Nakamura et al., 2005). As evidenced by retrograde tracing from these medullary raphe regions with FluoroGold (Fig. 4a and b), wheat germ agglutinin-conjugated horseradish peroxidase (Hosoya et al., 1987), and CTb (Hermann et al., 1997; Samuels et al., 2004), the DMH/DH region contains many neurons projecting to the medullary raphe regions. To examine whether these rapheprojecting DMH neurons are regulated by direct GABAergic inputs from POA neurons, the Sindbis virus and $\mathrm{CTb}$ were injected into the $\mathrm{POA}$ and the medullary raphe regions, respectively (Fig. 4c and d), and triple immunofluorescence labeling for EGFP, CTb, and VGAT, a marker for GABAergic axon terminals, was made in the DMH of animals in which Sindbis viral infection was caused in EP3 receptor-immunoreactive POA neurons (Fig. 4c, inset). Confocal laser-scanning microscopy showed close association of CTb-labeled neuronal cells with axon swellings double-positive for EGFP and VGAT immunoreactivities (Fig. 4e).

\section{Discussion}

The POA has been known as a fever center, since $\mathrm{PGE}_{2}$ acts as a powerful endogenous pyrogenic mediator in this area. An earlier study in which $\mathrm{PGE}_{1}$ was injected into various places throughout the rat subcortical brain tissue indicated that the POA is the sole region that can sense the E-series of PGs to produce fever (Williams et al., 1977). Scammell et al. (1996) located the detailed PG-sensitive sites within the POA by microinjecting a small dose $(1 \mathrm{ng} / 10 \mathrm{nl})$ of $\mathrm{PGE}_{2}$ and showed that such sites are in the MPO and MnPO. In these POA subregions, the EP3 subtype of PGE receptor is localized on many neuronal somata and dendrites (Nakamura et al., 1999, 2000). As evidenced by pseudorabies viral tracing, EP3 receptor-expressing POA neurons transneuronally innervate BAT (Yoshida et al., 2003), which is the major thermogenic effector in rodents (Rothwell, 1992). Furthermore, this PGE receptor subtype is known to be essential for fever induction (Ushikubi et al., 1998). Thus, $\mathrm{PGE}_{2}$ is considered to trigger fever-inducing neuronal pathways by acting on the EP3 receptor on POA neurons, specifically in the MPO and MnPO subregions. However, only limited information is available on the projection targets of pyrogen-sensing neurons in the POA. In the present study, we examined direct projections of EP3 receptor-expressing POA neurons to several hypothalamic regions in conjunction with their physiological function: the febrile response. Our retrograde tract tracing study revealed that EP3 receptor-expressing POA neurons directly projected to the $\mathrm{DMH}, \mathrm{DH}$, and $\mathrm{LH}$, and the present physiological analysis showed that within this projection field, only muscimol microinjections into the DMH and a ventral part of the $\mathrm{DH}$ inhibited febrile responses to intra-POA microinjection of $\mathrm{PGE}_{2}$. These results suggest that fever signals from the POA are transmitted to the $\mathrm{DMH} / \mathrm{DH}$ region through the direct projection of EP3 receptor-expressing POA neurons.

The DMH is an important site for various autonomic responses to certain stress stimuli (DiMicco et al., 2002), since inhibition of the DMH attenuates cardiovascular responses to experimental stress (Soltis \& DiMicco, 1992; Stotz-Potter et al., 1996a, 1996b). Disinhibition of DMH neurons evokes increases in BAT SNA, $\mathrm{T}_{\mathrm{BAT}}$, HR, and AP (Samuels et al., 2002, 2003; Zaretskaia et al., 2002; Cao et al., 2004; Horiuchi et al., 2004), which mimic the thermogenic and cardiovascular responses to stresses including systemic immune stress. Although the DMH receives many inputs from diverse brain regions (Thompson \& Swanson, 1998), these afferent pathways to the DMH have been poorly understood in conjunction with autonomic function. The present study, for the first time, associated the POA-DMH pathway with the fever mechanism by using EP3 receptor immunoreactivity as a marker for pyrogensensing neurons, and this anatomical finding was supported by the physiological analysis in this study. The present inhibitory effect of muscimol microinjections into the DMH on febrile 
responses to intra-POA $\mathrm{PGE}_{2}$ administration is consistent with the results from previous studies (Zaretskaia et al., 2003; Madden \& Morrison, 2004). However, muscimol injections made in these studies were limited within the DMH. By extending our physiological analysis to surrounding regions that receive a direct projection from EP3 receptor-expressing POA neurons, the present study provides a more detailed and specific functional mapping of the sites at which muscimol microinjections inhibited febrile responses evoked by $\mathrm{PGE}_{2}$ signals from the POA.

In this study, we examined the inhibitory effect of muscimol on maximum febrile responses by microinjecting a relatively high dose of $\mathrm{PGE}_{2}(60 \mathrm{ng})$, which is in the range generally used for intracerebroventricular injection in rats (Sugimoto et al., 1999). As mentioned above, however, the regions on which $\mathrm{PGE}_{2}$ can act to trigger fever are located only within the POA. Therefore, it is unlikely that the febrile responses elicited by microinjected $\mathrm{PGE}_{2}$ arose from $\mathrm{PGE}_{2}$ effects on neurons outside of the POA.

In the physiological experiments described here, we focused on the sympathetically mediated increases in BAT thermogenesis and corresponding increases in metabolic $\mathrm{CO}_{2}$ production elicited by intra-POA microinjection of $\mathrm{PGE}_{2}$. These responses represent only one of the physiological components contributing to the febrile response, itself only one of the components of the acute phase reaction to pathogen insult (For review, see Elmquist $e t$ al., 1997). In this regard, cutaneous vasoconstriction, restricting heat loss to the environment, is the other principal autonomic effector system activated to produce an elevated body temperature and is an important one engaged in fever production in humans lacking a significant complement of BAT. The increases in HR and AP we observed likely provide cardiovascular support for the febrile response: the increased cardiac output resulting from the elevated HR could augment BAT blood flow and provide for efficient corporal heat distribution, while the elevated AP may reflect the increased resistance in the peripheral vasculature and provide an increased driving force for blood flow through BAT. It is interesting to note that these cardiovascular adjustments indicate a marked reduction in the baroreceptor reflex gain, a modulation in central cardiovascular regulation also supporting the febrile response. Thus, although we did not measure them in these experiments, we expect that our microinjections of $\mathrm{PGE}_{2}$ into the POA affected other autonomic, and perhaps immune, efferent regulatory systems that play important roles in the febrile response. In addition, it is possible that the projections from the POA to targets other than the $\mathrm{DMH} / \mathrm{DH}$ contribute to these or to non-autonomic components of the acute phase reaction, such as reduced pain threshold or decreased appetite.

We found a direct projection to the LH from EP3 receptor-expressing POA neurons, but muscimol microinjections into the LH had no effect on the $\mathrm{PGE}_{2}$-evoked responses. Although it was recently reported that disinhibition of $\mathrm{LH}$ neurons produced BAT thermogenesis through the DMH and raphe pallidus nucleus (Cerri \& Morrison, 2005), this LH-evoked pathway might not be involved in febrile responses to a $\mathrm{PGE}_{2}$ action in the POA. The projection of EP3 receptor-expressing neurons to the $\mathrm{LH}$ could mediate other $\mathrm{PGE}_{2}$ functions that were not examined in the present study. The LH is involved in the regulation of food intake: lesions in the LH produced a profound anorexia (Keesey et al., 1984). Endotoxin administration induces anorexia as well as fever with mechanisms dependent on PG production (Lugarini et al., 2002), and these responses are at least partly dissociable events: anorexia associated with the acute-phase response to acute inflammation is not secondary to fever (Larson et al., 1996). Thus, it is possible that EP3 receptor-expressing POA neurons mediate anorexigenic signals to the $\mathrm{LH}$ in response to central $\mathrm{PGE}_{2}$ production during acute systemic inflammation.

The confocal laser-scanning analysis after triple immunolabeling in the present study revealed that DMH neurons projecting to medullary raphe regions received GABAergic inputs from 
POA neurons. The medullary raphe regions including the rostral part of the raphe pallidus nucleus and its surrounding raphe magnus nucleus contain putative sympathetic premotor neurons for febrile and thermoregulatory responses (Morrison, 2004; Nakamura, 2004; Nakamura et al., 2004; Nakamura et al., 2005). Inhibition of neurons in the medullary raphe regions blocks febrile responses to intra-POA $\mathrm{PGE}_{2}$ (Nakamura et al., 2002; Madden \& Morrison, 2003) and also BAT sympathetic thermogenic activity evoked by disinhibition of the DMH (Cao et al., 2004). Thus, it is possible that the medullary raphe-projecting DMH neurons mediate fever signals to the sympathetic premotor neurons. The previous result that disinhibition of DMH neurons with a $\mathrm{GABA}_{\mathrm{A}}$ receptor antagonist evoked autonomic responses similar to febrile responses (Samuels et al., 2002, 2003; Zaretskaia et al., 2002; Cao et al., 2004; Horiuchi et al., 2004) suggests that the DMH neurons mediating febrile responses are controlled by tonic GABAergic inputs. Taken together with our previous observation that the majority of EP3 receptor-expressing POA neurons were positive for a GABAergic neuronal marker (Nakamura et al., 2002), the present anatomical results support the idea that the tonic GABAergic inputs to fever-mediating DMH neurons are provided by EP3 receptor-expressing POA neurons. This idea is further supported by a previous result that transection caudal to the POA caused intense BAT thermogenesis (Chen et al., 1998).

Activation of EP3 receptor is generally considered to lead to inhibition of cellular functions by coupling with inhibitory GTP-binding proteins (Narumiya et al., 1999). Therefore, $\mathrm{PGE}_{2}-$ binding to the EP3 receptor on POA neurons possibly suppresses the activity of these neurons. If this possibility is taken into consideration, a hypothesis on the neuronal mechanism of $\mathrm{PGE}_{2}$-triggered fever, which strengthens our previous notion (Morrison, 2004; Nakamura, 2004), can be raised as follows (see Fig. 5). Under $\mathrm{PGE}_{2}$-free condition, fever-mediating DMH neurons are tonically inhibited by GABAergic inputs from EP3 receptor-expressing POA neurons. It is possible that the DMH neurons receive excitatory (glutamatergic) inputs from unknown regions (Madden \& Morrison, 2004), but cannot be activated due to stronger inhibition from the $\mathrm{POA}$ neurons. After infection, $\mathrm{PGE}_{2}$, which is produced in brain vasculature in response to immune signals, suppresses the tonic firing of the POA neurons through activation of the EP3 receptor, leading to disinhibition and activation of the DMH neurons possibly by the excitatory inputs from the unknown regions. The activated DMH neurons could send excitatory signals to the medullary raphe sympathetic premotor neurons, which in turn stimulate sympathetic outflows and finally develop fever. We have previously shown that EP3 receptor-expressing POA neurons also directly project to the medullary raphe regions (Nakamura et al., 2002), suggesting that these POA neurons can also exert a GABAergic inhibitory effect on the nervous system in the medullary raphe regions. It is possible that this POA-medullary raphe projection mediates fever signals to the sympathetic premotor neurons in a manner collaborative with the pathway through the DMH (Fig. 5) or mediates signals for responses in peripheral organs whose control does not involve the DMH.

Although the present study has focused on the direct pathway from the DMH to the medullary raphe regions, our current data do not exclude the possibility of the involvement of any other brain regions in febrile responses. Indeed, it was shown that activation of the caudal periaqueductal gray induced BAT thermogenesis (Chen et al., 2002) and that inhibition of the lateral/dorsolateral periaqueductal gray attenuated cardiovascular responses evoked by disinhibition of the DMH (da Silva Jr. et al., 2003). These periaqueductal gray regions might mediate fever signals from the POA to the medullary raphe regions through pathways remaining to be determined.

In summary, the present results propose the direct projection of EP3 receptor-expressing POA neurons to the DMH/DH region as a "functional" pathway for febrile responses, which are a part of stress-induced autonomic responses. Such stress signals trigger a variety of responses in peripheral thermoregulatory, cardiovascular, and endocrine effector organs, and many 
neuronal signals emanating these responses would be mediated by the DMH. However, it still remains to be answered how stress signals input into the DMH are converted to such diverse peripheral responses. The mechanism involving the tonic GABAergic inhibition presented in this study might be a key to answer this question.

\section{Acknowledgements}

We thank Drs. Takahiro Furuta, Kouichi Nakamura, and Nobuaki Tamamaki for providing Sindbis virus and antiEGFP antibody. This work was supported by NIH grant (NS40987 and DK57838) and by Grants-in-Aid for Scientific Research (No. 16200025, 16390059, and 17022020) from the Ministry of Education, Culture, Sports, Science and Technology of Japan. K.N. was a Research Fellow of the Japan Society for the Promotion of Science (No. 3814).

\section{Abbreviations}

\section{AP}

arterial pressure

\section{BAT}

brown adipose tissue

CTb

cholera toxin b-subunit

DH

dorsal hypothalamic area

DMH

dorsomedial hypothalamic nucleus

EGFP

enhanced green fluorescent protein

HR

heart rate

LH

lateral hypothalamic area

MAP

mean arterial pressure

MnPO

median preoptic nucleus

MPO

medial preoptic area

POA

preoptic area

PG

prostaglandin

SNA

sympathetic nerve activity

$\mathbf{T}_{\text {BAT }}$

brown adipose tissue temperature 
$\mathbf{T}_{\text {rec }}$

rectal temperature

VGAT

vesicular GABA transporter

\section{References}

Atkins E, Bodel P. Fever. N Engl J Med 1972;286:27-34. [PubMed: 4550084]

Cao WH, Fan W, Morrison SF. Medullary pathways mediating specific sympathetic responses to activation of dorsomedial hypothalamus. Neuroscience 2004;126:229-240. [PubMed: 15145088]

Cerri M, Morrison SF. Activation of lateral hypothalamic neurons stimulates brown adipose tissue thermogenesis. Neuroscience 2005;135:627-638. [PubMed: 16125857]

Chen XM, Hosono T, Yoda T, Fukuda Y, Kanosue K. Efferent projection from the preoptic area for the control of non-shivering thermogenesis in rats. J Physiol (Lond) 1998;512:883-892. [PubMed: 9769429]

Chen XM, Nishi M, Taniguchi A, Nagashima K, Shibata M, Kanosue K. The caudal periaqueductal gray participates in the activation of brown adipose tissue in rats. Neurosci Lett 2002;331:17-20. [PubMed: 12359313]

da Silva LG Jr, de Menezes RCA, dos Santos RAS, Campagnole-Santos MJ, Fontes MAP. Role of periaqueductal gray on the cardiovascular response evoked by disinhibition of the dorsomedial hypothalamus. Brain Res 2003;984:206-214. [PubMed: 12932855]

DiMicco JA, Samuels BC, Zaretskaia MV, Zaretsky DV. The dorsomedial hypothalamus and the response to stress: part renaissance, part revolution. Pharmacol Biochem Behav 2002;71:469-480. [PubMed: 11830181]

Elmquist JK, Scammell TE, Saper CB. Mechanisms of CNS response to systemic immune challenge: the febrile response. Trends Neurosci 1997;20:565-570. [PubMed: 9416669]

Furuta T, Tomioka R, Taki K, Nakamura K, Tamamaki N, Kaneko T. In vivo transduction of central neurons using recombinant Sindbis virus: Golgi-like labeling of dendrites and axons with membranetargeted fluorescent proteins. J Histochem Cytochem 2001;49:1497-1507. [PubMed: 11724897]

Hermann DM, Luppi PH, Peyron C, Hinckel P, Jouvet M. Afferent projections to the rat nuclei raphe magnus, raphe pallidus and reticularis gigantocellularis pars $\alpha$ demonstrated by iontophoretic application of choleratoxin (subunit b). J Chem Neuroanat 1997;13:1-21. [PubMed: 9271192]

Horiuchi J, McAllen RM, Allen AM, Killinger S, Fontes MAP, Dampney RAL. Descending vasomotor pathways from the dorsomedial hypothalamic nucleus: role of medullary raphe and RVLM. Am J Physiol 2004;287:R824-R832.

Hosoya Y, Ito R, Kohno K. The topographical organization of neurons in the dorsal hypothalamic area that project to the spinal cord or to the nucleus raphé pallidus in the rat. Exp Brain Res 1987;66:500506. [PubMed: 3609196]

Keesey RE, Corbett SW, Hirvonen MD, Kaufman LN. Heat production and body weight changes following lateral hypothalamic lesions. Physiol Behav 1984;32:309-317. [PubMed: 6718556]

Kluger MJ. Fever: role of pyrogens and cryogens. Physiol Rev 1991;71:93-127. [PubMed: 1986393]

Larson SJ, Collins SM, Weingarten HP. Dissociation of temperature changes and anorexia after experimental colitis and LPS administration in rats. Am J Physiol 1996;271:R967-R972. [PubMed: 8897989]

Lugarini F, Hrupka BJ, Schwartz GJ, Plata-Salaman CR, Langhans W. A role for cyclooxygenase-2 in lipopolysaccharide-induced anorexia in rats. Am J Physiol 2002;283:R862-R868.

Madden CJ, Morrison SF. Excitatory amino acid receptor activation in the raphe pallidus area mediates prostaglandin-evoked thermogenesis. Neuroscience 2003;122:5-15. [PubMed: 14596844]

Madden CJ, Morrison SF. Excitatory amino acid receptors in the dorsomedial hypothalamus mediate prostaglandin-evoked thermogenesis in brown adipose tissue. Am J Physiol 2004;286:R320-R325.

Matsumura K, Cao C, Ozaki M, Morii H, Nakadate K, Watanabe Y. Brain endothelial cells express cyclooxygenase-2 during lipopolysaccharide-induced fever: light and electron microscopic immunocytochemical studies. J Neurosci 1998;18:6279-6289. [PubMed: 9698320] 
Moriyoshi K, Richards LJ, Akazawa C, O’Leary DDM, Nakanishi S. Labeling neural cells using adenoviral gene transfer of membrane-targeted GFP. Neuron 1996;16:255-260. [PubMed: 8789941]

Morrison SF. Raphe pallidus neurons mediate prostaglandin $\mathrm{E}_{2}$-evoked increases in brown adipose tissue thermogenesis. Neuroscience 2003;121:17-24. [PubMed: 12946696]

Morrison SF. Central pathways controlling brown adipose tissue thermogenesis. News Physiol Sci 2004;19:67-74. [PubMed: 15016906]

Nakamura K. Fever-inducing sympathetic neural pathways. J Therm Biol 2004;29:339-344.

Nakamura K, Kaneko T, Yamashita Y, Hasegawa H, Katoh H, Ichikawa A, Negishi M. Immunocytochemical localization of prostaglandin EP3 receptor in the rat hypothalamus. Neurosci Lett 1999;260:117-120. [PubMed: 10025713]

Nakamura K, Kaneko T, Yamashita Y, Hasegawa H, Katoh H, Negishi M. Immunohistochemical localization of prostaglandin EP3 receptor in the rat nervous system. J Comp Neurol 2000;421:543569. [PubMed: 10842213]

Nakamura K, Li YQ, Kaneko T, Katoh H, Negishi M. Prostaglandin EP3 receptor protein in serotonin and catecholamine cell groups: a double immunofluorescence study in the rat brain. Neuroscience 2001;103:763-775. [PubMed: 11274793]

Nakamura K, Matsumura K, Hübschle T, Nakamura Y, Hioki H, Fujiyama F, Boldogköi Z, König M, Thiel HJ, Gerstberger R, Kobayashi S, Kaneko T. Identification of sympathetic premotor neurons in medullary raphe regions mediating fever and other thermoregulatory functions. J Neurosci 2004;24:5370-5380. [PubMed: 15190110]

Nakamura K, Matsumura K, Kaneko T, Kobayashi S, Katoh H, Negishi M. The rostral raphe pallidus nucleus mediates pyrogenic transmission from the preoptic area. J Neurosci 2002;22:4600-4610. [PubMed: 12040067]

Nakamura K, Matsumura K, Kobayashi S, Kaneko T. Sympathetic premotor neurons mediating thermoregulatory functions. Neurosci Res 2005;51:1-8. [PubMed: 15596234]

Narumiya S, Sugimoto Y, Ushikubi F. Prostanoid receptors: structures, properties, and functions. Physiol Rev 1999;79:1193-1226. [PubMed: 10508233]

Oka T, Oka K, Kobayashi T, Sugimoto Y, Ichikawa A, Ushikubi F, Narumiya S, Saper CB. Characteristics of thermoregulatory and febrile responses in mice deficient in prostaglandin EP1 and EP3 receptors. J Physiol (Lond) 2003;551:945-954. [PubMed: 12837930]

Oka T, Oka K, Scammell TE, Lee C, Kelly JF, Nantel F, Elmquist JK, Saper CB. Relationship of EP14 prostaglandin receptors with rat hypothalamic cell groups involved in lipopolysaccharide fever responses. J Comp Neurol 2000;428:20-32. [PubMed: 11058222]

Paxinos, G.; Watson, C. The Rat Brain in Stereotaxic Coordinates. 4. Academic Press; San Diego: 1998.

Rothwell NJ. Eicosanoids, thermogenesis and thermoregulation. Prostaglandins Leukot Essent Fatty Acids 1992;46:1-7. [PubMed: 1321446]

Samuels BC, Zaretsky DV, DiMicco JA. Tachycardia evoked by disinhibition of the dorsomedial hypothalamus in rats is mediated through medullary raphe. J Physiol (Lond) 2002;538:941-946. [PubMed: 11826177]

Samuels BC, Zaretsky DV, DiMicco JA. Dorsomedial hypothalamic sites where disinhibition evokes tachycardia correlate with location of raphe-projecting neurons. Am J Physiol 2004;287:R472-R478.

Scammell TE, Elmquist JK, Griffin JD, Saper CB. Ventromedial preoptic prostaglandin $E_{2}$ activates fever-producing autonomic pathways. J Neurosci 1996;16:6246-6254. [PubMed: 8815905]

Simerly RB, Swanson LW. Projections of the medial preoptic nucleus: a Phaseolus vulgaris leucoagglutinin anterograde tract-tracing study in the rat. J Comp Neurol 1988;270:209-242. [PubMed: 3259955]

Soltis RP, DiMicco JA. Hypothalamic excitatory amino acid receptors mediate stress-induced tachycardia in rats. Am J Physiol 1992;262:R689-R697. [PubMed: 1348912]

Stotz-Potter EH, Morin SM, DiMicco JA. Effect of microinjection of muscimol into the dorsomedial or paraventricular hypothalamic nucleus on air stress-induced neuroendocrine and cardiovascular changes in rats. Brain Res 1996a;742:219-224. [PubMed: 9117398]

Stotz-Potter EH, Willis LR, DiMicco JA. Muscimol acts in dorsomedial but not paraventricular hypothalamic nucleus to suppress cardiovascular effects of stress. J Neurosci 1996b;16:1173-1179. [PubMed: 8558246] 
Sugimoto N, Simons CT, Romanovsky AA. Vagotomy does not affect thermal responsiveness to intrabrain prostaglandin $E_{2}$ and cholecystokinin octapeptide. Brain Res 1999;844:157-163. [PubMed: 10536272]

Swanson, LW. Brain Maps: Structure of the Rat Brain. Elsevier; Amsterdam: 1992.

Tamamaki N, Nakamura K, Furuta T, Asamoto K, Kaneko T. Neurons in Golgi-stain-like images revealed by GFP-adenovirus infection in vivo. Neurosci Res 2000;38:231-236. [PubMed: 11070189]

Thompson RH, Swanson LW. Organization of inputs to the dorsomedial nucleus of the hypothalamus: a reexamination with Fluorogold and PHAL in the rat. Brain Res Rev 1998;27:89-118. [PubMed: 9622601]

Ushikubi F, Segi E, Sugimoto Y, Murata T, Matsuoka T, Kobayashi T, Hizaki H, Tuboi K, Katsuyama M, Ichikawa A, Tanaka T, Yoshida N, Narumiya S. Impaired febrile response in mice lacking the prostaglandin E receptor subtype EP3. Nature 1998;395:281-284. [PubMed: 9751056]

Williams JW, Rudy TA, Yaksh TL, Viswanathan CT. An extensive exploration of the rat brain for sites mediating prostaglandin-induced hyperthermia. Brain Res 1977;120:251-262. [PubMed: 832123]

Yamagata K, Matsumura K, Inoue W, Shiraki T, Suzuki K, Yasuda S, Sugiura H, Cao C, Watanabe Y, Kobayashi S. Coexpression of microsomal-type prostaglandin E synthase with cyclooxygenase-2 in brain endothelial cells of rats during endotoxin-induced fever. J Neurosci 2001;21:2669-2677. [PubMed: 11306620]

Yoshida K, Nakamura K, Matsumura K, Kanosue K, König M, Thiel HJ, Boldogköi Z, Toth I, Roth J, Gerstberger R, Hübschle T. Neurons of the rat preoptic area and the raphe pallidus nucleus innervating the brown adipose tissue express the prostaglandin E receptor subtype EP3. Eur J Neurosci 2003;18:1848-1860. [PubMed: 14622218]

Zaretskaia MV, Zaretsky DV, DiMicco JA. Role of the dorsomedial hypothalamus in thermogenesis and tachycardia caused by microinjection of prostaglandin $\mathrm{E}_{2}$ into the preoptic area in anesthetized rats. Neurosci Lett 2003;340:1-4. [PubMed: 12648744]

Zaretskaia MV, Zaretsky DV, Shekhar A, DiMicco JA. Chemical stimulation of the dorsomedial hypothalamus evokes non-shivering thermogenesis in anesthetized rats. Brain Res 2002;928:113125. [PubMed: 11844478] 

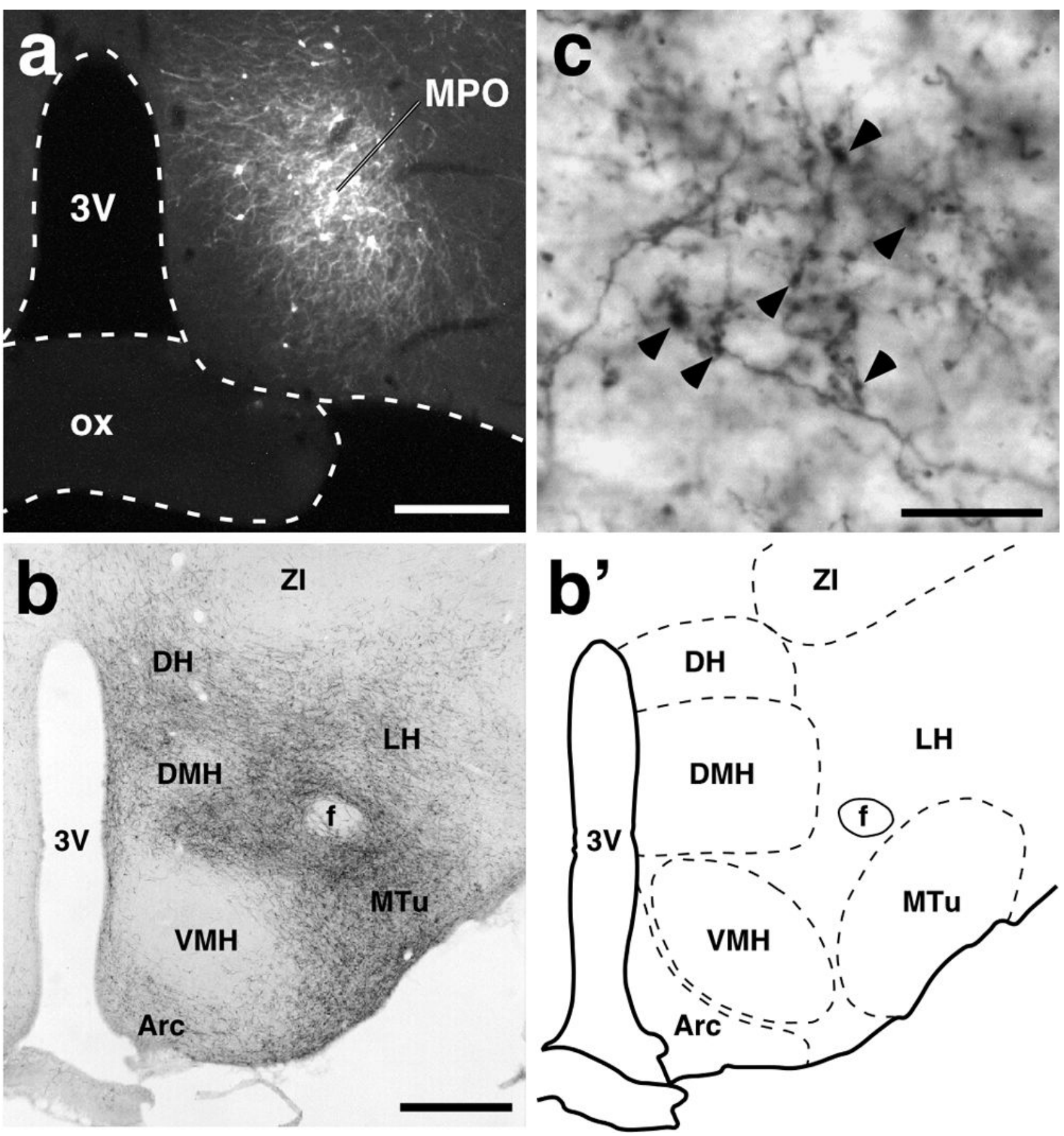

Fig. 1.

Anterograde neural tract tracing from the POA to hypothalamic regions at the rostrocaudal level of the DMH. (a) Injection of recombinant Sindbis virus into the MPO. Infected cells expressed a membrane-targeted form of EGFP; these cells formed a cluster and many neuronal fibers with EGFP fluorescence extended from the cell cluster. (b) Distribution of EGFPimmunoreactive fibers in a coronal section at the rostrocaudal level of the DMH (bregma -3.30 $\mathrm{mm}$ ). Many axon fibers derived from infected neurons in the MPO were distributed in several hypothalamic regions. ( $b^{\prime}$ ) Illustration of the anatomical map of the section shown in (b). (c) EGFP immunoreactivity in the DMH. Boutons (arrowheads) as well as fibers exhibited EGFP immunoreactivity. 3V, third ventricle; Arc, arcuate nucleus; f, fornix; ox, optic chiasm; MTu, 
medial tuberal nucleus; VMH, ventromedial hypothalamic nucleus; ZI, zona incerta. Scale bars, $0.3 \mathrm{~mm}$ (a), $0.5 \mathrm{~mm}$ (b), $20 \mu \mathrm{m}$ (c). 

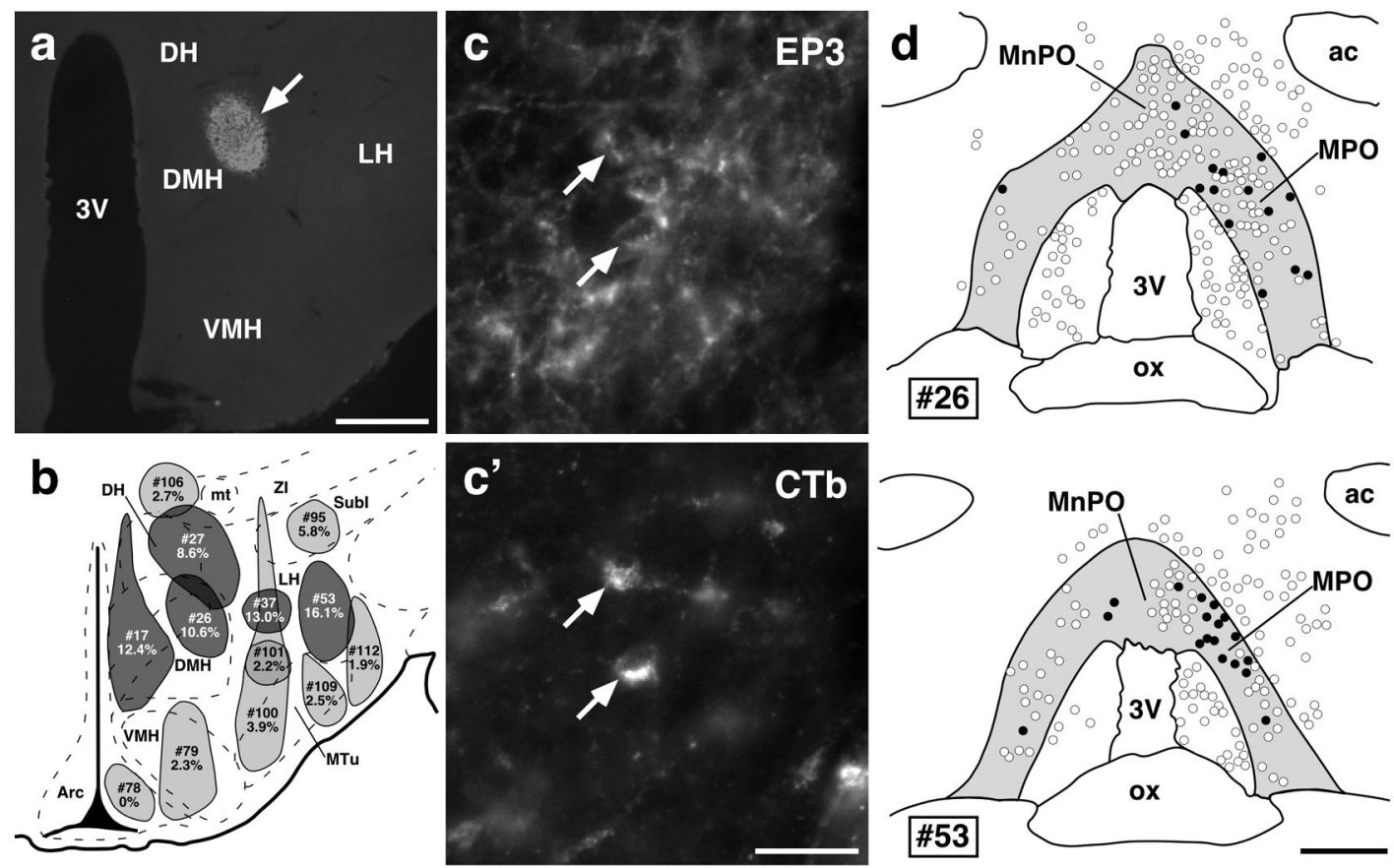

Fig. 2.

EP3 receptor-expressing POA neurons directly project to the hypothalamic regions. (a) A representative view of CTb injection sites in the DMH (arrow; showing case \# 26). (b) Composite drawing of $\mathrm{CTb}$ injection sites (gray regions) and percentages of EP3 receptorimmunoreactive neurons in CTb-labeled ones within the EP3 receptor-immunoreactive POA regions (see (d)). Injection sites that were positioned in the hypothalamic regions at around bregma $-3.30 \mathrm{~mm}$ were drawn on a brain map taken from an atlas by Paxinos \& Watson (1998). Top and bottom numbers identify injection cases and percentages for each injection case, respectively. Numbers of cells are shown in Table 1. CTb injections into the DMH, DH, and LH, which showed relatively high percentages, were colored dark gray. (c) and (c') POA neuronal cell bodies double-labeled with EP3 receptor and CTb immunoreactivities (arrows). The photomicrographs were taken at the same site under different conditions of excitation. (d) Distribution of POA neurons labeled with $\mathrm{CTb}$ (open circles) and with both CTb and EP3 receptor immunoreactivities (filled circles) after a unilateral CTb injection into the DMH (\#26) or into the LH (\#53). Injection was made on the right side, and the injection case numbers correspond to those in (b). All CTb-labeled cells distributed in the shown regions were drawn. EP3 receptor-immunoreactive regions are colored gray. ac, anterior commissure; $\mathrm{mt}$, mammillothalamic tract; SubI, subincertal nucleus. Scale bars, $0.5 \mathrm{~mm}$ (a and d), $30 \mu \mathrm{m}$ (c and $\left.c^{\prime}\right)$. 
a
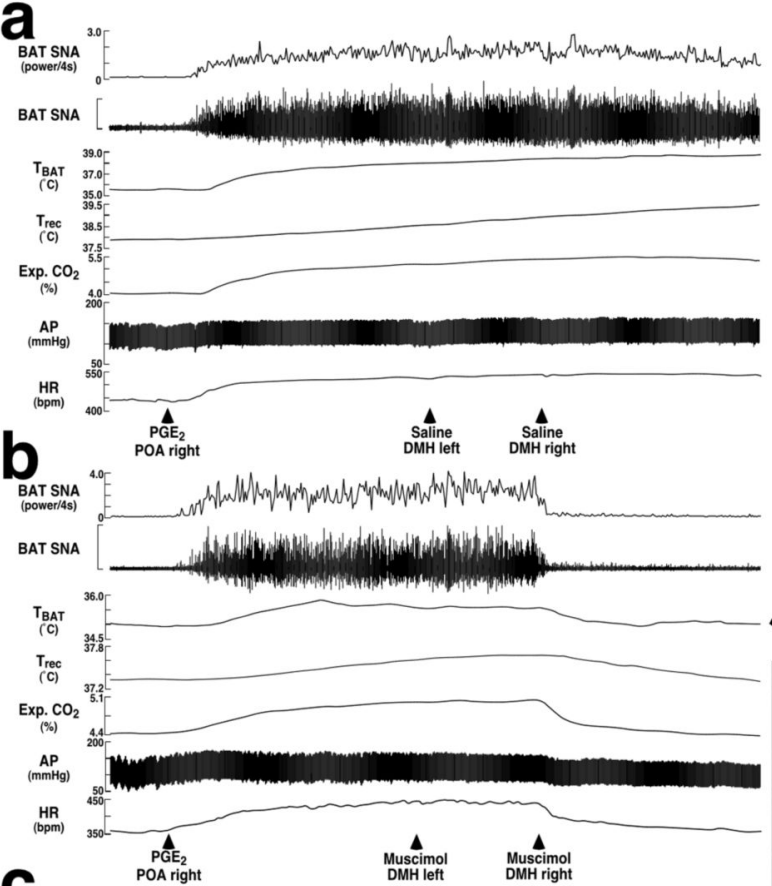

C:

BAT SNA

BAT SNA

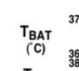

(C)
Trec
(C)
(C)

(C)
Exp. $\left.{ }_{(\%)}\right)$

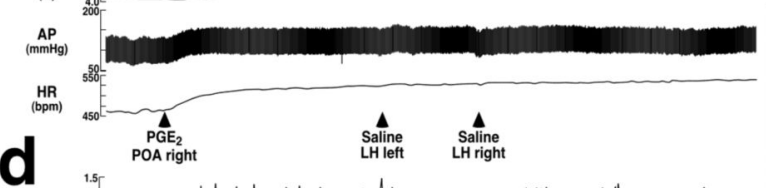

d

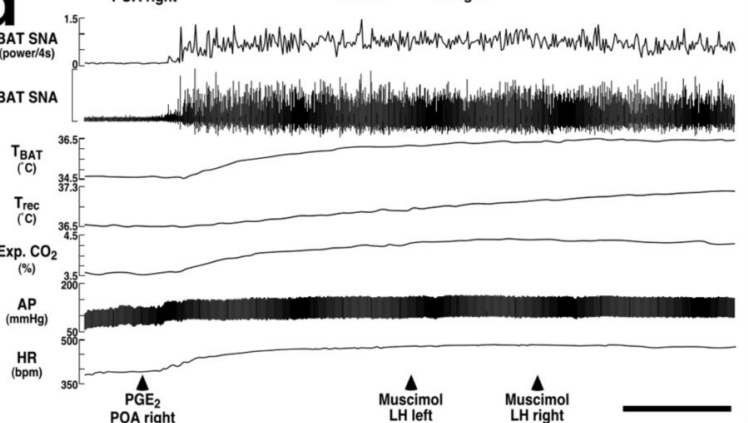

Fig. 3.

e

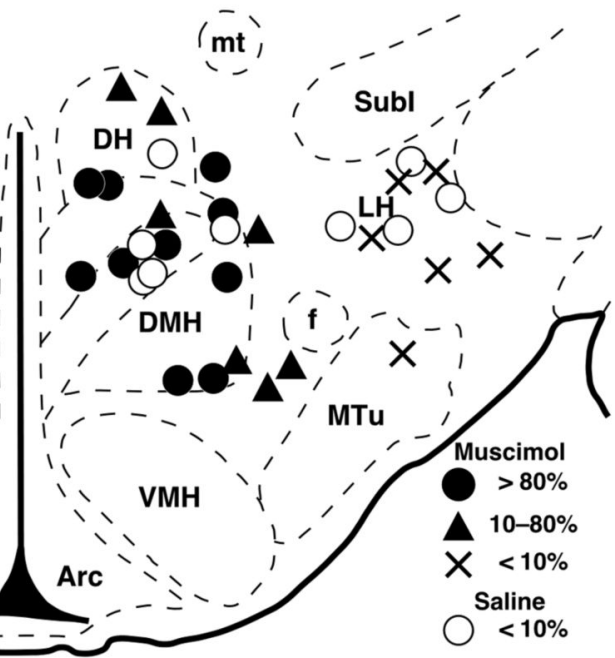

\section{$f$}

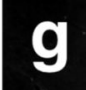

MnPo
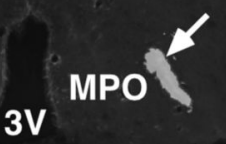

ox
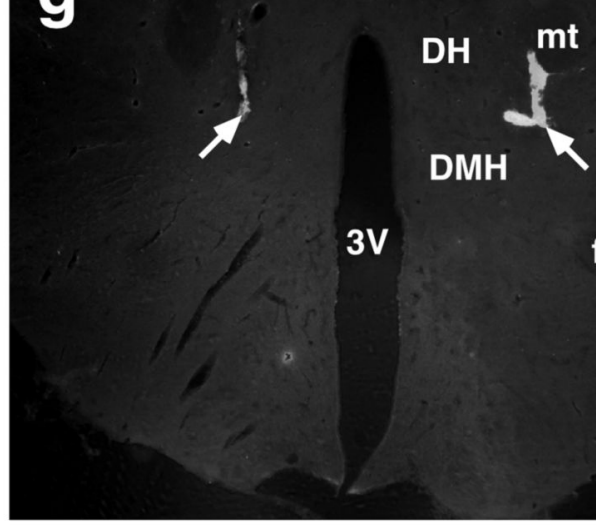

3V

f

Effects of microinjections of muscimol into hypothalamic regions on $\mathrm{PGE}_{2}$-evoked increases in BAT SNA, $\mathrm{T}_{\mathrm{BAT}}, \mathrm{T}_{\text {rec }}$, expired (Exp.) $\mathrm{CO}_{2}$, AP, and HR. (a-d) Changes in the physiological variables after bilateral microinjections of saline (a and c) or muscimol (b and d) into the DMH ( $a$ and b) or LH (c and d) following thermogenic and cardiovascular responses to unilateral microinjection of $\mathrm{PGE}_{2}$ into the POA. Horizontal scale bar represents $5 \mathrm{~min}$ for (a)-(d). Vertical scale bars for BAT SNA traces represent $100 \mu \mathrm{V}$ in (a) and (d), $250 \mu \mathrm{V}$ in (b), and $50 \mu \mathrm{V}$ in (c). (e) Composite drawing of sites of saline and muscimol microinjections with their inhibitory effects on the increase in BAT SNA by intra-POA PGE 2 . Microinjections into the hypothalamic regions were made bilaterally and their sites were positioned symmetrically. Injection sites on 
the right side were drawn on a brain map (bregma $-3.30 \mathrm{~mm}$ ). The inhibitory effect was expressed as inhibition percentage of $\mathrm{PGE}_{2}$-evoked increase in BAT SNA and graded as follows: $>80 \%$, full inhibition (filled circles); $10-80 \%$, partial inhibition (triangles); $<10 \%$, no inhibition (crosses). Inhibition percentages by saline injections were always less than $10 \%$ (open circles). (f) and (g) Representative views of a $\mathrm{PGE}_{2}$ microinjection into the MPO (f) and muscimol microinjections into the $\mathrm{DMH}(\mathrm{g})$. Each injection site is clearly identified as a cluster of fluorescent beads (arrows). Scale bar, $0.5 \mathrm{~mm}$ (f and $\mathrm{g}$ ). 


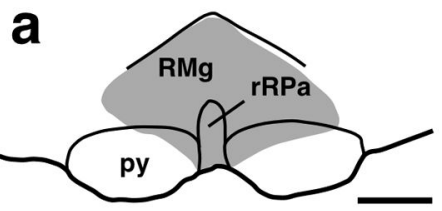

b

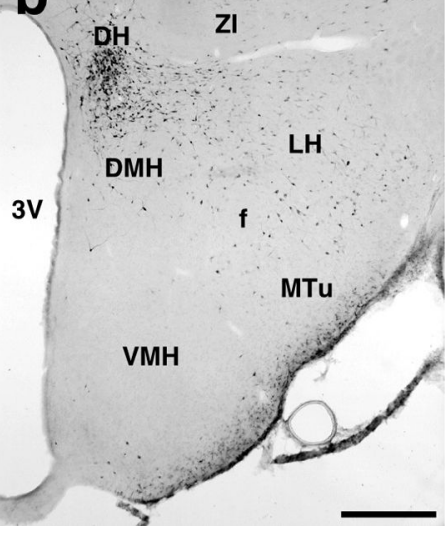

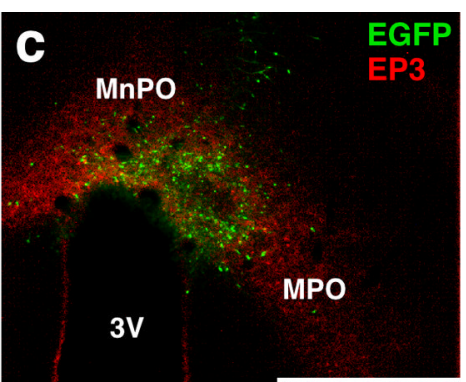
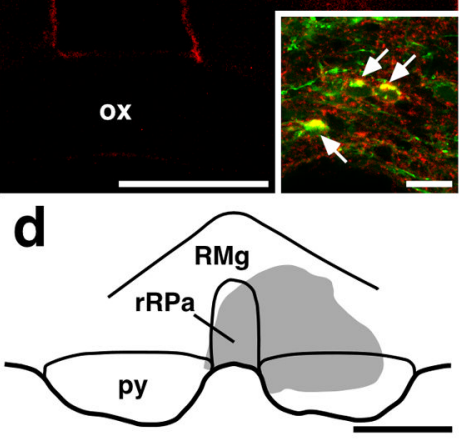
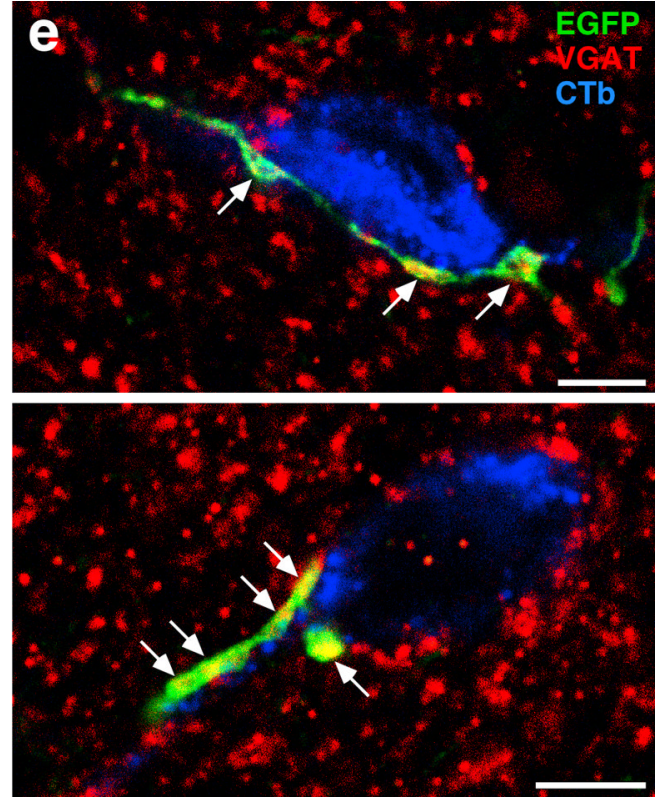

Fig. 4.

DMH neurons projecting to medullary raphe regions receive GABAergic inputs from POA neurons. (a) Site of Fluoro-Gold injection (gray region) into the rostral part of the raphe pallidus nucleus (rRPa) and the raphe magnus nucleus (RMg). (b) Distribution of Fluoro-Gold-labeled neurons in a coronal section at the rostrocaudal level of the DMH (bregma $-3.30 \mathrm{~mm}$ ) after the injection shown in (a). (c) Injection of Sindbis virus into the POA. Many infected cells, which exhibited EGFP fluorescence (green), were distributed in the region where EP3 receptorimmunoreactive neurons (red) were localized. Inset shows infection of EP3 receptorimmunoreactive neurons with the Sindbis virus; there were neurons exhibiting both EP3 receptor immunoreactivity (red) and EGFP fluorescence (green) (arrows) in the injection site. (d) Site of CTb injection (gray region) into the rRPa and RMg. (e) Confocal laser-scanning microscopy in DMH sections triple immunofluorescence-stained for EGFP (green), VGAT (red), and $\mathrm{CTb}$ (blue). The signals for these three labelings are shown using pseudo-colors. Axon swellings double-labeled with EGFP and VGAT immunoreactivities were closely associated with CTb-immunoreactive neuronal cells (arrowheads). Two representative cases found in the DMH are shown. Scale bars, $0.5 \mathrm{~mm}(\mathrm{a}-\mathrm{d}), 20 \mu \mathrm{m}$ (inset in c), $5 \mu \mathrm{m}$ (e). 


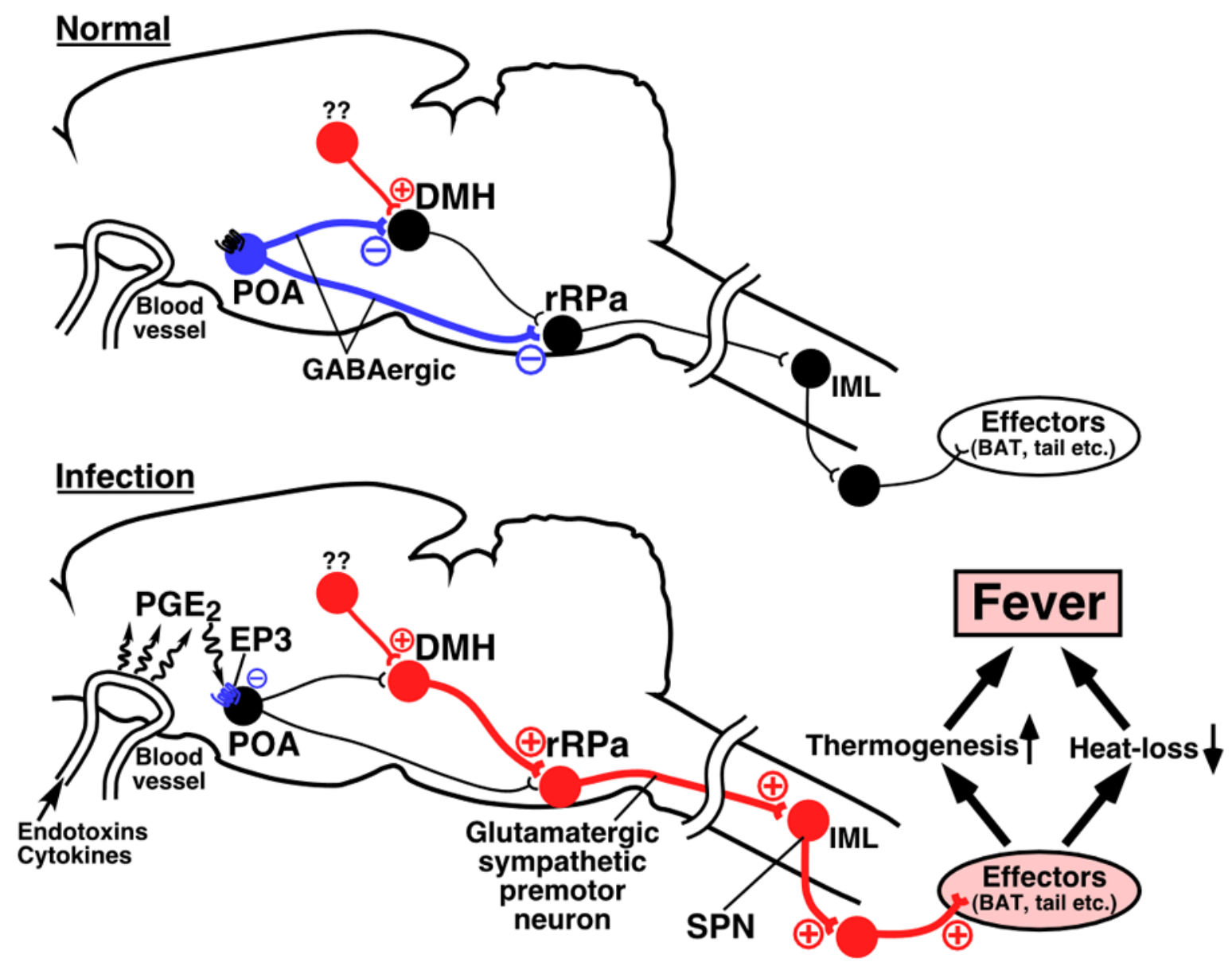

Fig. 5.

A current hypothesis on the neural pathways mediating fever on the basis of the previous and present findings. Under $\mathrm{PGE}_{2}$-free condition (Normal), neurons in the DMH and rRPa are tonically inhibited by inputs from EP3 receptor-expressing GABAergic neurons in the POA. It is possible that the $\mathrm{DMH}$ neurons receive excitatory inputs from unknown regions, but cannot be activated due to stronger inhibition from the POA neurons. After infection (Infection), $\mathrm{PGE}_{2}$, which is produced in brain vasculature in response to immune signals, suppresses the tonic firing of the POA neurons by activating the EP3 receptor, and hereby, the DMH and rRPa neurons are released from the tonic inhibition. Excitation of the DMH neurons, which can be triggered by the excitatory inputs from the unknown regions, activates sympathetic premotor neurons in the rRPa, which in turn stimulate the sympathetic output system and finally develop fever. Blue, red, and black circles denote cell bodies of activated inhibitory neurons, activated excitatory neurons, and suppressed neurons, respectively. IML, intermediolateral cell column; SPN, sympathetic preganglionic neuron. 
TABLE 1

Number and percentage of $\mathrm{CTb}$-labeled neurons in the POA that were EP3 receptor-immunoreactive for each of CTb injections into hypothalamic regions

\begin{tabular}{lll}
\hline Injection case & $\begin{array}{l}\text { EP3+, CTb+ cells/ } \\
\text { total CTb+ cells }\end{array}$ & $\%$ \\
\hline$\# 17$ & $22 / 178$ & $12.4^{*}$ \\
$\# 26$ & $28 / 263$ & $10.6^{*}$ \\
$\# 27$ & $41 / 478$ & $8.6^{*}$ \\
$\# 37$ & $41 / 315$ & $13.0^{*}$ \\
$\# 53$ & $37 / 230$ & $16.1^{*}$ \\
$\# 78$ & $0 / 61$ & 0 \\
$\# 79$ & $3 / 129$ & 2.3 \\
$\# 100$ & $9 / 155$ & 5.8 \\
$\# 101$ & $13 / 333$ & 3.9 \\
$\# 106$ & $7 / 313$ & 2.2 \\
$\# 109$ & $4 / 146$ & 2.7 \\
$\# 112$ & $4 / 161$ & 2.5 \\
& $2 / 103$ & 1.9 \\
\hline
\end{tabular}

Cells were counted within EP3 receptor-immunoreactive POA regions (see Fig. $2 \mathrm{~d}$ ) in every six 20- $\mu \mathrm{m}$-thick frontal sections. All the injection sites are shown in Fig. 2b. Asterisks indicate CTb injection cases that showed relatively high percentages (dark gray regions in Fig. 2b). 
TABLE 2

Changes in $\mathrm{PGE}_{2}$-evoked increases in physiological variables following microinjections into the DMH or LH

\begin{tabular}{llll}
\hline & $\begin{array}{l}\text { Saline into DMH } \\
(\mathbf{n}=\mathbf{4})\end{array}$ & $\begin{array}{l}\text { Muscimol into DMH } \\
(\mathbf{n = 6})\end{array}$ & $\begin{array}{l}\text { Saline into LH } \\
(\mathbf{n}=\mathbf{4})\end{array}$ \\
\hline BAT SNA & $+0.3 \pm 4 \%$ & $-96 \pm 5 \% * *$ & $\begin{array}{l}\text { Muscimol into LH } \\
(\mathbf{n}=\mathbf{5})\end{array}$ \\
$\mathrm{T}_{\text {BAT }}$ & $+0.1 \pm 0.2^{\circ} \mathrm{C}$ & $-0.6 \pm 0.2^{\circ} \mathrm{C}$ & $+2 \pm 2 \%$ \\
$\mathrm{~T}_{\text {rec }}$ & $+0.3 \pm 0.3^{\circ} \mathrm{C}$ & $-0.2 \pm 0.1^{\circ} \mathrm{C}$ & $+0.4 \pm 0.2^{\circ} \mathrm{C}$ \\
Expired $\mathrm{CO}_{2}$ & $+0.2 \pm 0.1 \%$ & $-0.5 \pm 0.1 \% * *$ & $+0.5 \pm 0.3^{\circ} \mathrm{C}$ \\
MAP & $-2 \pm 5 \mathrm{mmHg}$ & $-17 \pm 4 \mathrm{mmHg}^{*}$ & $+0.1 \pm 0.1 \%$ \\
HR & $+8 \pm 4 \mathrm{bpm}$ & $-44 \pm 17 \mathrm{bpm}$ & $+4 \pm 3 \mathrm{mmHg}$ \\
& & & $+9 \pm 6 \mathrm{bpm}$ \\
\hline
\end{tabular}

The data represent the mean \pm SEM. Changes in PGE2-evoked increases in physiological variables at 3 min (BAT SNA, TBAT, expired CO2, MAP, and $\mathrm{HR})$ and $10 \mathrm{~min}\left(\mathrm{~T}_{\mathrm{rec}}\right)$ after bilateral microinjections of saline or muscimol into the DMH or LH are shown. Changes in BAT SNA are expressed as percentage of peak PGE2-evoked increase. Positive and negative values mean increase and inhibition from PGE2-evoked peak values, respectively.

$*, * * * * *$ Significant difference from group saline-injected into the same hypothalamic region;

* $P<0.05$,

** $P<0.01$,

**** $P<0.001$ 